\title{
PSIKOTERAPI DALAM PERSPEKTIF BIMBINGAN KONSELING ISLAMI
}

\author{
Lahmuddin \\ Fakultas Dakwah IAIN Sumatera Utara \\ Jl. Willem Iskandar Pasar V Medan Estate, 20371 \\ e-mail: lahmuddinlubis@yahoo.co.id.
}

\begin{abstract}
Abstrak: Psikoterapi merupakan proses penyembuhan kejiwaan konseli/klien melalui beberapa terapi tertentu. Dalam tulisan ini penulis mengkaji bagaimana landasan dasar psikoterapi dalam Islam. Penulis memperlihatkan bahwa Islam memiliki dasardasar yang kukuh dalam proses psikopterapi. Proses penyembuhan atau perawatan dilaksanakan melalui intervensi psikis dengan metode dan teknik yang didasarkan kepada al-Qur'an dan Sunnah Rasulullah SAW. Dalam perspektif bimbingan konseling Islami, perawatan (treatment) yang disarankan/dianjurkan oleh konselor (terapis) kepada klien dalam mengatasi/mengurangi permasalahan klien, baik permasalahan yang berkaitan dengan kejiwaan, spiritual, moral (akhlak), dan fisik (jasmaniyah) adalah dengan terapi kejiwaan melalui ibadah-ibadah wajib dalam agama, peningkatan kesabaran, taubat, zikir dan doa.
\end{abstract}

\begin{abstract}
Psychotherapy in the Perspective of Islamic Counseling Guidance. Psychotherapy is healing proses of client's psychic state by certain theraphic means. In this writing, the author studies the main principles of psychotherapy in Islam. The author throuw some lights that Islam laid down firm foundations in psychotherapic process. The treatment procedure is done through psychic intervention the technique and method of which are based on the precepts of the Qur'an and the Prophetic tradition (sunnah). In the perspective of Islamic counseling guidance, recommended treatment by the counselor to the client in solving the latters' problems in such as those related to psychic, moral, spiritual physical, are through religious compulsory rituals, keeping up patience, repented and ask for God forgiveness as well as parayers.
\end{abstract}

Kata kunci : Psikoterapi, penyembuhan, rawatan, bimbingan konseling Islami

\section{Pendahuluan}

Bimbingan dan Konseling Islami merupakan salah satu disiplin ilmu yang semakin hari semakin diperlukan oleh masyarakat dan merupakan bagian penting serta integral 
dalam sistem pendidikan di Indonesia. Sebagai sebuah layanan profesional, kegiatan layanan bimbingan dan konseling tidak bisa dilakukan secara sembarangan, tetapi harus dibangun dan berpijak dari suatu landasan yang kokoh, yang didasarkan pada hasilhasil pemikiran dan penelitian yang mendalam. Dengan adanya pijakan yang jelas dan kokoh diharapkan pengembangan layanan bimbingan dan konseling, baik dalam tataran teoritik maupun praktik, semakin lebih baik dan bisa dipertanggungjawabkan serta mampu memberikan manfaat yang besar bagi kehidupan manusia. Khususnya bagi para penerima jasa layanan.

Secara teoritis, bimbingan dan konseling memiliki sejumlah tujuan. Menurut Tang Chee Yee, tujuannya adalah menolong konseli/klien mempelajari, memahami pengalaman, nilai, sikap dan perlakuan, melayani keperluan klien untuk mengembangkan potensi dan kemampuan mereka, menolong klien memahami diri mereka dan orang lain dengan mendalam, menolong klien memilih dan merancang hidup mereka dengan baik, melayani keperluan klien supaya ia dapat berkembang ke tahap yang sepatutnya, menolong klien menyadari kekuatan dan kelemahan mereka, menjadikan klien lebih tegas, dan dapat menyesuaikan diri dengan lingkungan, mewujudkan keseimbangan fisik dan mental klien, dan menolong klien supaya berkemampuan membuat penyesuaian dan perubahan tingkah laku yang perlu.

Sebagaimana tujuannya, bahwa Bimbingan dan Konseling Islami ingin membantu berbagai permasalahan hidup seorang klien. Salah satu tema sentral dalam bidang studi ini adalah psikoterapi. Dalam hal ini, psikoterapi (psychotherapy) adalah suatu proses penyembuhan atau perawatan (treatment) yang dilakukan oleh konselor (terapis) yang profesional kepada klien melalui pendekatan psikologi, al-Qur'an dan hadis, dengan tujuan agar klien dapat keluar dari masalah yang dihadapinya, baik masalah kejiwaan, spiritual (keagamaan), akhlak maupun masalah fisik. Psikoterapi dapat dilakukan melalui beberapa cara seperti meningkatkan keimanan dan ibadah klien, mendalami dan mengamalkan al-Qur'an, terapi kejiwaan melalui salat, melalui zakat, melalui puasa, melalui haji, melalui kesabaran, melalui istighfar dan taubat serta terapi melalui zikir dan doa.

Tulisan ini akan membahas psikoterapi dalam perspektif Bimbingan Konseling Islami. Secara khusus, akan dibahas pengertian dan model Psikoterapi, penyebab munculnya masalah dalam diri manusia, dan model-model Psikoterapi dalam al-Qur'an dan hadis, serta tujuan Psikoterapi dalam Bimbingan Konseling Islami.

\section{Pengertian dan Model Psikoterapi}

Terdapat dua istilah yang sering digunakan konselor dalam memberikan penyembuhan atau treatment terhadap klien, yaitu terapi (therapy) dan psikoterapi (psychotherapy). Menurut Andi Mappiare, terapi (therapy) adalah suatu proses korektif atau kuratif, atau penyembuhan, 
lazim dipakai dalam bidang medikal (kedokteran), istilah terapi kerap digunakan secara bergantian dengan konseling (counseling) dan psikoterapi (psychotherapy). ${ }^{1}$

Sedangkan psikoterapi (psychotherapy) berasal dari dua suku kata yaitu psycho dan therapy. Psycho berarti jiwa, dan therapy berarti penyembuhan. Dengan demikian, psikoterapi (psychotheapy) adalah penyembuhan jiwa. ${ }^{2}$ Psikoterapi juga dapat diartikan sebagai pengobatan, yaitu pengobatan dan perawatan gangguan psikis melalui metode psikologis. ${ }^{3}$

Kata terapi (therapy) dalam bahasa Inggeris memiliki arti pengobatan dan penyembuhan, sedangkan dalam bahasa Arab kata terapi sepadan dengan al-istisyfấ' yang berasal dari syafâ-yasyfi-syifâ' yang artinya menyembuhkan. Istilah ini telah digunakan oleh Muhammad 'Abd al-'Azîz al-Khâlidî. ${ }^{4}$ Kata-kata syifâ' banyak dijumpai dalam al-Qur'an, di antaranya pada surah Yûnus/10: 57 dan al-Isrâ'/17: 82, yaitu:

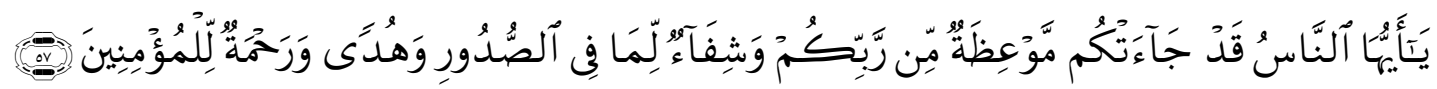

Hai manusia, sesungguhnya telah datang kepadamu pelajaran dari Tuhanmu dan penyembuh bagi penyakit-penyakit (yang berada) dalam dada dan petunjuk serta rahmat bagi orangorang yang beriman (Q.S. Yûnus/10: 57). ${ }^{5}$

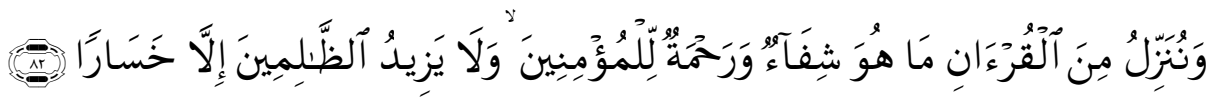

Dan kami turunkan dari al-Qur'an suatu yang menjadi penawar dan rahmat bagi orangorang yang beriman dan al-Qur'an itu tidaklah menambah kepada orang-orang yang zalim selain kerugian (Q.S. al-Isrâ'/17: 82). ${ }^{6}$

Psikoterapi (psychotherapy) yaitu pengobatan jiwa dengan cara kebatinan atau penerapan teknik khusus (termasuk pendekatan konseling) pada penyembuhan penyakit mental atau kesulitan-kesulitan penyesuaian diri setiap hari, atau penyembuhan melalui keyakinan agama dan diskusi dengan para pakar, baik guru, ustaz maupun konselor.

Psikoterapi dapat juga dikatakan perawatan dengan menggunakan alat-alat psikologis terhadap permasalahan yang berasal dari kehidupan emosional, di mana seorang ahli sengaja menciptakan hubungan profesional dengan klien/pasien dengan tujuan menghilangkan, h. 334 .

${ }^{1}$ Andi Mappiare, Kamus Istilah Konseling \& Terapi (Jakarta: RajaGrafindo Persada, 2006),

${ }^{2}$ Samsul Munir Amin, Bimbingan dan Konseling Islam (Jakarta: AMZAH, 2010), h. 186.

${ }^{3}$ Iin Tri Rahayu, Psikoterapi Perspektif Islam \& Psikologi Kontemporer (Malang: UIN Malang Press, 2009), h. 191.

${ }^{4} I b i d$, h. 188

${ }^{5}$ Departemen Agama RI, Al-Qur'an dan Terjemahannya (Jakarta: Lintas Media, 2006), h. 289. ${ }^{6}$ Ibid, h. 396. 
mengubah, atau menurunkan gejala-gejala yang ada; memperbaiki tingkah laku yang rusak; serta meningkatkan pertumbuhan serta perkembangan kepribadian yang positif. ${ }^{7}$

Dengan demikian, terapi atau psikoterapi tidak bisa terlepaskan dari bimbingan konseling, karena pada dasarnya manusia tidak bisa luput dari permasalahan, baik permasalahan itu kecil dan sederhana di mana seseorang bisa mengatasinya dengan kekuatan mental dan agama yang ia yakini, maupun masalah yang besar, sulit dan rumit, di mana seseorang tidak bisa keluar dari tanpa bantuan, arahan, dan bimbingan orang lain, dalam hal ini termasuk peranan konselor yang profesional.

Diyakini atau tidak, sesungguhnya manusia tidak pernah luput dari masalah, mulai dari masalah yang paling sederhana hingga masalah yang rumit dan kompleks, baik masalah itu berkaitan dengan pribadi, pendidikan, karier, ekonomi, keluarga, agama maupun masalah sosial. ${ }^{8}$ Menurut Samuel T. Gladding, ${ }^{9}$ masalah yang paling banyak melanda manusia adalah masalah karir, pendidikan, pribadi dan sosial.

Sementara itu, menurut Iin Tri Rahayu, ${ }^{10}$ objek psikoterapi Islam adalah adalah manusia secara utuh yaitu yang berkaitan dengan gangguan pada empat hal berikut. Pertama, mental, yaitu yang berhubungan dengan pikiran, akal, ingatan atau proses yang berasosiasi dengan pikiran akal dan ingatan, seperti mudah lupa, malas berpikir, tidak mampu berkosentrasi, picik, tidak dapat mengambil suatu keputusan dengan baik dan benar, bahkan tidak memiliki kemampuan membedakan antara yang halal dan haram, antara yang bermanfaat dan tidak bermanfaat. Kedua, spiritual, yaitu yang berhubungan dengan masalah ruh, semangat atau jiwa, religius, yang berhubungan dengan agama, keimanan, kesalehan dan menyangkut transendental seperti syirik, nifak, fasik, kufur, lemah keyakinan dan tertutup atau terhijabnya alam ruh, alam malakut dan alam gaib, semua akibat kedurhakaan dan pengingkaran kepada Allah. Ketiga, moral (akhlak), yaitu suatu keadaan yang melekat pada jiwa manusia, yang akan melahirkan perbuatan-perbuatan dengan mudah tanpa melalui proses pemikiran, pertimbangan atau penelitian, sikap mental atau watak yang terjabarkan dalam bentuk berpikir, berbicara, dan bertingkah laku. Keempat, fisik (jasmaniyah). Memang dapat diakui bahwa tidak semua gangguan fisik dapat disembuhkan dengan psikoterapi Islam, kecuali atas izin dan ma'unah Allah SWT.

Dalam perspektif Bimbingan Konseling Islami, psikoterapi bisa dilakukan secara individual maupun secara kelompok. Menurut Gerald Corey, ${ }^{11}$ Psikoterapi tersebut dapat

${ }^{7}$ Amin, Bimbingan dan Konseling, h. 189.

${ }^{8}$ Lahmuddin Lubis, Landasan Formal Bimbingan Konseling di Indonesia (Bandung: Citapustaka Media Perintis, 2011), h. 197.

${ }^{9}$ Samuel T. Gladding, Counseling A Comprehensive Profession (Englewood Cliffs: Prentice Hall. Inc, 1996), h. 329.

${ }^{10}$ Rahayu, Psikoterapi Perspektif, h. 210-211.

${ }^{11}$ Gerald Corey, Teori dan Praktek Konseling \& Psikoterapi, terj. Koeswara (Bandung: Refika Aditama, 2005), h. 6-8. 
berorientasi kepada beberapa aspek, baik kognitif, tingkah laku dan tindakan. Gerald Corey menjelaskan bahwa ada delapan model konseling dan psikoterapi yang bisa dilakukan konselor terhadap klien yang bermasalah atau yang mengalami gangguan, yaitu:

1. Terapi Psikoanalitik. Tokoh utama terapi ini adalah Freud, Carl Jung, Adler, Sullivan, Rank, Horney dan Erikson. Terapi psikoanalitik adalah suatu teori kepribadian, sistem filsafat dan metode psikoterapi.

2. Terapi Eksistensial Humanistik. Tokoh utama terapi ini adalah May, Maslow, Frankl dan Jourard. Pendekatan ini dikembangkan sebagai reaksi melawan psikoanalisis dan Behaviorisme yang dianggap tidak adil dalam mempelajari manusia.

3. Terapi Client Centered. Tokoh utama terapi ini adalah Carl Roger's. Terapi Client Centered menaruh kepercayaan dan meminta tanggung jawab yang lebih besar kepada klien dalam menangani berbagai permasalahan. Dengan kata lain, terapi ini lebih dipusatkan kepada klien untuk mencari jalan keluar dari setiap persoalan yang dihadapi klien, konselor hanya sebagai mediator dan motivator, sedangkan pemilihan dan penentuan jenis terapi diserahkan sepenuhnya kepada klien.

4. Terapi Gestalt. Tokoh utama atau pendiri terapi ini adalah Fritz Perls. Terapi ini merupakan eksperimental yang menekankan kesadaran dan integrasi, yang muncul sebagai reaksi melawan terapi analitik, serta mengintegrasikan fungsi jiwa dan badan.

5. Terapi Transaksional. Tokoh utama terapi ini adalah Eric Berne. Terapi ini cenderung ke arah aspek-aspek kognitif dan behavioral, dan dirancang untuk membantu orangorang dalam mengevaluasi putusan-putusan yang telah dibuatnya menurut kelayakan sekarang.

6. Terapi Tingkah laku. Tokoh utama dari terapi ini adalah Wolpe, Eysenck, Lazarus dan Salter. Terapi ini merupakan penerapan prinsip-prinsip belajar pada penyelesaian gangguang-gangguan tingkah laku yang spesifik. Hasil-hasilnya merupakan bahan bagi eksperimentasi lebih lanjut. Terapi tingkah laku secara sinambung berada dalam proses penyempurnaan.

7. Terapi Emosional Emotif. Tokoh utama terapi ini adalah Albert Ellis. Suatu model yang amat didaktik, berorientasi kognitif tindakan, serta menekankan peran pemikiran dan sistem-sistem kepercayaan sebagai akar masalah-masalah pribadi.

8. Terapi Realitas. Tokoh utama terapi ini adalah William Glasser. Suatu model terapi yang dikembangkan sebagai reaksi melawan terapi konvensional. Terapi realitas adalah terapi jangka pendek yang berfokus pada saat sekarang, menekankan kekuatan pribadi, dan pada dasarnya merupakan jalan di mana para klien bisa belajar tingkah laku yang lebih realistik dan karenanya bisa mencapai keberhasilan.

Kedelapan model konseling dan psikoterapi ini dapat dikelompokkan ke dalam tiga kategori. Kategori pertama adalah psikodinamika yang berlandaskan pada pemahaman, motivasi serta rekonstruksi kepribadian, dan merupakan terapi psikoanalitik. Kategori 
kedua adalah terapi-terapi yang berorientasi eksperiensial dan relasi yang berlandaskan psikologi humanistik meliputi terapi-terapi eksistensial, terapi clien-centered dan terapi Gestalt. Kategori ketiga adalah terapi-terapi berorientasi pada tingkah laku, rasionalkognitif dan tindakan yang mencakup analisis Transaksional, terapi-terapi tingkah laku, terapi rasional-emostif, dan terapi relaitias.

Sedangkan proses terapi dan penyembuhan melalui pendekatan Islami sering disebut dengan istilah istisyfâ'. Salah satu metodenya adalah doa. Menurut Isep Zainal Arifin, ${ }^{12}$ psikoterapi Islam dapat diistilahkan sebagai al-istsyfâ' bi al-Qur'ân wa al-Du'â', yaitu penyembuhan terhadap penyakit-penyakit dan gangguan psikis yang didasarkan kepada tuntunan nilai-nilai al-Qur'an dan doa.

Doa bagi umat Islam merupakan suatu kekuatan yang luar biasa. Doa merupakan suatu alat yang paling kuat untuk menolak sesuatu yang tidak diinginkan, juga doa dapat mendatangkan sesuatu yang diminta. Tetapi pengaruh doa itu akan berbeda-beda menurut kadar iman, keyakinan dan harapan seseorang. Jika ada doa yang tidak dikabulkan oleh Allah SWT., hal itu bisa saja disebabkan karena di dalam hati orang yang berdoa terdapat rasa permusuhan, atau mungkin karena lemah imannya atau kurang bersungguh-sungguh ketika berdoa kepada Allah SWT. Tidak terkabulnya doa ada kalanya karena adanya hal yang menghambat terkabulnya doa itu seperti memakan barang haram, dosa-dosa yang melekat di dalam hati, terlalu cinta kepada dunia dan kelengahan (kelalaian) hati. Hal ini sesuai dengan Sabda Rasulullah SAW. yang diriwayatkan oleh alTirmidzî "ud'ullâha wa antum muqinuna bi al-ijâbah" (berdoalah kepada Allah dengan keyakinan bahwa doamu akan dikabulkan). Sementara itu, menurut Ibnu Qayyim, ${ }^{13}$ doa adalah obat yang paling kuat untuk menyembuhkan suatu penyakit, tetapi hati yang lupa kepada Allah akan memengaruhi kemanjuran doa tersebut.

Para konselor dapat memilih jenis terapi yang diberikan kepada klien sesuai dengan jenis masalah atau penyakit yang diderita klien, dengan diketahuinya jenis serta model konseling dan psikoterapi ini. Sehingga klien yang mempunyai masalah dapat tertolong dan keluar dari masalah yang dihadapinya.

Karena itu, masalah sekecil apapun yang muncul ke permukaan haruslah ditangani secara arif dan bijaksana, sehingga masalah tersebut tidak sampai membesar dan kompleks yang pada gilirannya dapat mengganggu kestabilan seseorang (klien) dan sulit diatasi atau diselesaikan. Demikian juga sebaliknya, masalah yang besar sekalipun bisa diatasi dan diselesaikan, jika diformulasi dengan baik melalui pendekatan atau psikoterapi (penyembuhan) yang tepat, yaitu dengan menggunakan pendekatan al-Qur'an dan Sunnah.

\footnotetext{
${ }^{12}$ Isep Zainal Arifin, Bimbingan Penyuluhan Islam Pengembangan Dakwah Melalui Psikoterapi Islam (Jakarta: RajaGrafindo Persada, 2009), h. 23-24.

${ }^{13}$ Ibnu Qayyim, Terapi Penyakit dengan al-Qur'an dan Sunnah, terj. Achmad Sunarto (Jakarta: Pustaka Amani, 1999), h. 7-8.
} 


\section{Penyebab Munculnya Masalah}

Sebelum terapi diberikan kepada klien yang mengalami permasalahan atau gangguan kejiwaan, maka setiap konselor haruslah mengetahui penyebab munculnya masalah atau gangguan tersebut, sehingga terapi, penyembuhan atau obat yang diberikan kepada konseli/klien sesuai dengan permasalahan yang dirasakan oleh klien.

Masalah atau penyakit mental yang melanda klien ada yang berasal dari dalam diri seseorang; dan ada juga yang berasal dari luar diri manusia. Untuk mengetahui sumbersumber masalah bagi manusia perlu digali faktor-faktor penyebabnya sehingga seseorang dapat menghindari masalah tersebut, demikian juga halnya bagi konselor, dengan mengetahui penyebab masalah terjadi pada seseorang/klien, maka konselor lebih mudah memberi terapi yang sesuai kepada klien tersebut.

Menurut Erhamwida ${ }^{14}$ ada tiga macam penyebab utama manusia mempunyai masalah. Pertama, jasad/fisik yang kurang kuat/sehat. Secara umum orang yang mengalami gangguan fisik, dapat berpengaruh pada kondisi psikis atau kejiwaan seseorang, meskipun tidak berarti setiap kali orang mengalami gangguan fisik akan merasakan penderitaan psikis sekaligus. Sebaliknya kondisi psikis seseorang akan turut memengaruhi fisiknya, namun demikian, tidak semua orang yang menderita gangguan psikisnya berpengaruh kepada fisiknya. Dalam kenyataannya, ada orang yang kurang sempurna fisiknya, tetapi ia merasakan kebahagiaan dalam kehidupannya. Hal itu berarti meskipun keadaan fisik seseorang berpengaruh terhadap psikis seseorang, namun masih terbuka peluang ia akan merasakan kebahagiaan dalam hidup ini. Tetapi, secara teoritis tidak bisa dibantah bahwa jika keadaan fisik seseorang lemah atau cacat, maka hal itu sedikit atau banyak akan memengaruhi psikisnya.

Kedua, qalb/hati yang kotor. Hati yang kotor atau tidak bersih bisa menjadi sumber utama munculnya kegelisahan, kekhawatiran, ketidakpuasan, kecemasan, ketakutan dan kebosanan. Sebaliknya, hati yang suci, bersih yang diberi cahaya oleh Allah akan menjadikan seseorang merasakan ketenangan dan ketentraman serta mendapatkan dan merasakan kebahagiaan. Jika ditinjau dari perspektif al-Qur'an, maka pada jiwa atau hati manusia itu ada bibit penyakit, dan jika penyakit itu tidak segera dibuang atau dihilangkan, maka penyakit itu akan semakin besar dan berbahaya, bukan saja pada orang yang mempunyai masalah itu, tetapi juga pada orang lain. Ungkapan ini terlihat pada firman Allah:

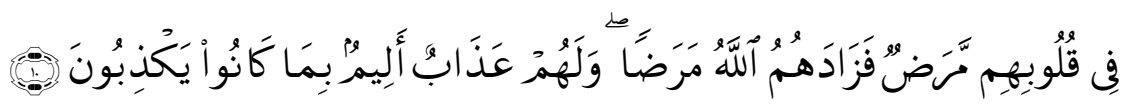

Dalam hati mereka ada penyakit, lalu ditambah Allah penyakitnya; dan bagi mereka siksa yang pedih, disebabkan mereka berdusta (Q.S. al-Baqarah/2: 10). ${ }^{15}$

${ }^{14}$ Erhamwilda, Konseling Islami (Yogyakarta: Graha Ilmu, 2009), h. 57-62.

${ }^{15}$ Departemen Agama, Al-Qur'an dan Terjemahannya, h. 3. 
Berdasarkan ayat ini, penyakit yang paling banyak diderita oleh manusia adalah penyakit hati, yaitu iri dan dendam. Jika kedua jenis penyakit ini masih bersarang pada diri/jiwa seseorang, maka hidupnya tidak pernah bahagia dan tenang, bahkan sebaliknya seseorang itu akan merasakan kegelisahan, kecemasan dan kesusahan.

Allah SWT. berfirman:

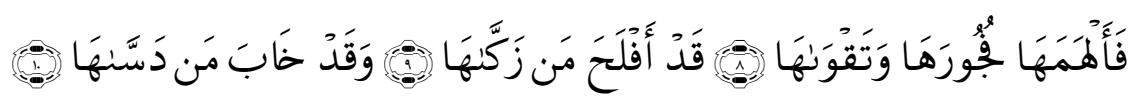

Maka Allah mengilhamkan kepada jiwa itu (jalan) kefasikan dan ketakwaannya. Sesungguhnya beruntunglah orangyang mensucikannya (jiwa itu). Dan sungguh rugi orangyang mengotorinya (Q.S. al-Syams/91: 8-10). ${ }^{16}$

Ayat ini memberikan isyarat bahwa pada dasarnya telah ada dalam setiap jiwa/ diri seseorang itu bibit atau potensi untuk menjadi orang yang baik (taqwâ) dan bibit atau potensi untuk menjadi orang yang jahat/fasik (fujûr). Kefasikan (fujûraha) mengandung makna bahwa setiap orang telah memilki bibit penyakit atau permasalahan. Karena itu, bibit penyakit itu harus segera dibuang, paling tidak dikawal agar tidak menjadi besar dan berbahaya.

Dalam kaitan ini, setiap konselor harus memupuk dan menyuburkan potensi yang baik (taqwâ) sehingga seseorang itu dapat merasakan kebahagian dan dekat kepada Tuhan-Nya, dan sebaliknya memperkecil serta mengarahkan potensi fasik (fujûr) agar seseorang terhindar dari problem atau penyakit mental.

Erhamwilda mengatakan bahwa hati/jiwa manusia dapat dibagi kepada tiga bagian. 1) Hati/jiwa yang sakit (qalb al-marîdh). Hati/jiwa yang sakit dapat diibaratkan seperti cermin yang kotor atau tidak terawat, sehingga setiap orang yang menggunakannya akan memantulkan hasil atau cahaya yang tidak baik. Orang yang menderita qalb al-marîdh akan sulit menilai sesuatu secara jujur dan adil. Orang yang memiliki jiwa seperti ini iri melihat orang yang sukses, iri melihat orang yang mendapat rizki, dan hatinya selalu cemas dan gelisah. Hati/jiwa seperti inilah tempat bersarangnya penyakit atau problem. Jika penyakit seperti ini tidak cepat ditanggulangi atau diberikan terapi, maka klien tersebut akan menderita berkepanjangan yang bukan saja dapat merusak dan berbahaya bagi orang lain, tetapi juga dapat berbahaya dan merusak diri yang bersangkutan. 2) Hati/Jiwa yang Mati (qalb al-mayyit). Hati/jiwa yang mati adalah hati yang kerdil, keras dan hati sepenuhnya dikusai oleh hawa nafsu. Hari-hari yang dilaluinya penuh dengan kesombongan dan keangkuhan. Orang yang mempunyai hati seperti ini tidak pernah mengenal kasih sayang. Ia melakukan apa saja yang dikehendakinya tanpa pernah memperhatikan norma dan etika yang berlaku. Hawa nafsu telah menulikan telinganya, membutakan matanya, membodohkan akal pikirannya dan menutupi hati nuraninya, sehingga ia tidak

${ }^{16}$ Ibid, h. 896. 
mampu lagi membedakan yang hak dan batil, yang halal dan yang haram, karena yang menjadi pengendali dirinya adalah hawa nafsu dan bukan akal. Orang yang memiliki hati atau jiwa yang mati seakan-akan hanya memiliki jasad, tetapi roh atau nalurinya seakan-akan telah mati, orang seperti ini dapat dikatakan seperti bangkai yang berjalan. 3) Hati yang selamat (qalb al-salîm). Hati yang selamat adalah hati yang terkendali, hati yang selalu dihiasi dengan zikir dan istighfar kepada Allah SWT. Orang yang memiliki qalb al-salîm adalah orang yang hidup penuh dengan ketenangan, kebahagiaan dan ketentraman. Walaupun dari aspek material keadaannya sangat miskin dan sederhana, tetapi dari aspek immaterial, emosional, perasaan dan hati/jiwanya sangat kaya. Ia selalu dekat kepada Allah, akrab dan santun kepada sesama serta peduli kepada orangorang miskin dan tidak punya. Orang yang memiliki hati seperti ini adalah orang yang mengedepankan keimanan kepada Allah SWT., iman menjadi motor atau penggerak dalam segala aktivitasnya. Hati/jiwa seperti inilah yang diistilahkan dalam al-Qur'an sebagai jiwa yang tenang (muthma'innah). Hal ini sesuai dengan penjelasan firman Allah SWT.:

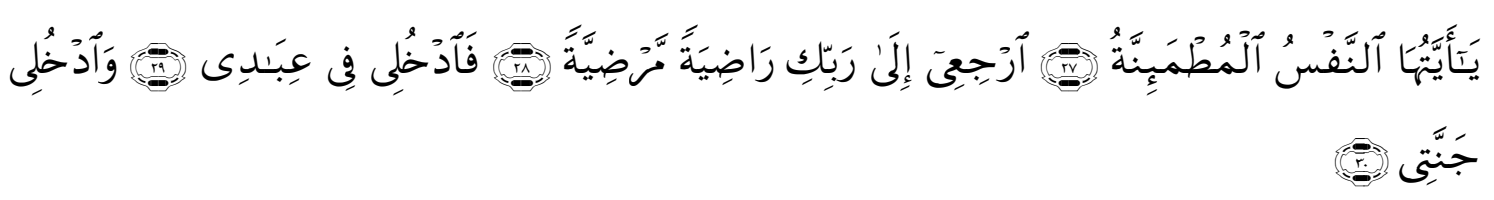

Hai jiwa yang tenang. Kembalilah kepada Tuhanmu dengan hati yang puas lagi diridai-Nya. Maka masuklah ke dalam jamaah hamba-hamba-Ku, masuklah ke dalam surga-Ku (Q.S. al-Fajr/89: 27-30). ${ }^{17}$

Ketiga, akal yang tidak digunakan sebagaimana mestinya. Akal yang tidak berfungsi secara maksimal atau tidak digunakan sebagaimana mestinya bisa mendatangkan masalah. Allah SWT. telah membekali manusia dengan akal agar manusia mampu memikirkan berbagai hal dalam menjalankan aktivitas hidupnya. Akal yang dibimbing oleh ruh yang suci dan penggunaannya mengacu kepada wahyu Allah, maka ia akan menemukan caracara yang baik dan tepat dalam kehidupan ini sehingga pada akhirnya ia mendapatkan ketenangan dan kebahagiaan.

Salah satu fungsi akal yang utama adalah agar manusia mampu berpikir. Berpikir dalam berbagai referensi psikologi dimaknai sebagai proses menghubung-hubungkan antara data yang satu dengan yang lainnya untuk menyelesaikan masalah. Dalam al-Qur'an banyak dijelaskan bagaimana proses berpikir terjadi, dan berpikir bukan sekedar untuk membaca fenomena alam, tetapi juga agar manusia mampu memecahkan masalah hidupnya, dan mampu melihat kebesaran Allah di atas segalanya.

Salah satu penyebab timbulnya masalah atau penyakit mental pada seseorang

${ }^{17} I b i d$, h. 893. 
adalah apabila manusia tersebut jauh dari Allah SWT. Ketika seseorang jauh dari Allah atau melalaikan kewajiban dan tanggung jawabnya terhadap Allah, maka seseorang itu akan mengalami banyak permasalahan, kehidupannya semakin sempit, penuh kecemasan, kegelisahan dan bahkan permasalahan atau problem datang silih berganti, orang-orang seperti ini tidak akan pernah merasakan kebahagiaan dan ketentraman dalam hidupnya kendatipun ia memiliki harta yang banyak dan jabatan yang tinggi. ${ }^{18}$

Hal ini sesuai dengan pernyataan Allah SWT.:

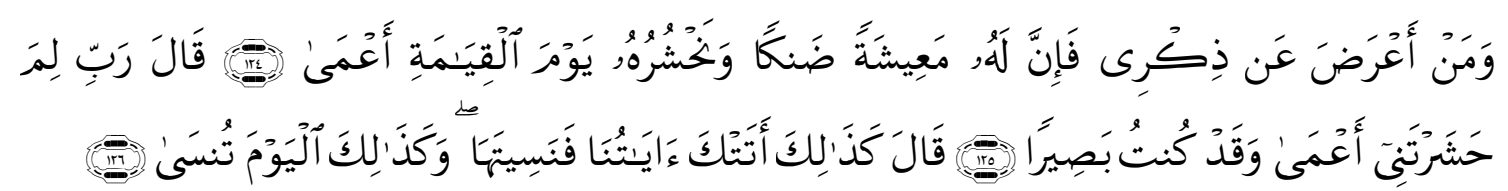

Dan barangsiapa berpaling dari peringatan-Ku, maka sesungguhnya baginya penghidupan yang sempit, dan kami akan menghimpunkannya pada hari kiamat dalam keadaan buta. Berkatalah ia: 'Ya Tuhanku, mengapa Engkau menghimpunkan aku dalam keadaan buta, padahal aku dahulunya adalah seorang yang melihat?.' Allah berfirman: 'Demikianlah, telah datang kepadamu ayat-ayat kami, maka kamu melupakannya, dan begitu (pula) pada hari ini kamu pun dilupakan (Q.S. Thâhâ/20: 124-126). ${ }^{19}$

Karena itu, penyebab yang paling menentukan mudahnya seseorang mengalami masalah (problem) adalah ketika manusia jauh dari Allah SWT. atau melalaikan kewajiban kepada Allah. Orang yang jauh dari Allah jiwanya mudah dihinggapi penyakit psikis seperti gelisah, sedih, cemas, was-was, iri, dan penyakit psikis lainnya. Sifat-sifat negatif seumpama ini menyebabkan mudahnya muncul penyakit fisik seperti maag, jantung, darah tinggi dan sebagainya. Penyakit fisik yang disebabkan penyakit psikis itulah yang disebut penyakit psikosomatik.

Sebaliknya, bagi orang yang memiliki fisik yang kurang sempurna atau organ tubuh yang tidak bisa berfungsi secara maksimal, akan semakin mudah mengalami penyakit psikis atau mental. Tetapi, jika seseorang dekat kepada Allah SWT., taat dalam beribadah, senantiasa berzikir dan selalu mendekatakan diri kepada Allah serta menjauhi dari segala larangan-Nya, maka peluangnya untuk mendapatkan kebahagiaan dan ketentraman batin sangat terbuka. Hal yang paling menentukan untuk mendapatkan ketenangan, kebahagiaan dan sehatnya psikis seseorang adalah kedekatan diri kepada sang pencipta.

Sementara itu, menurut Ahmad Mubarok ${ }^{20}$ ada lima macam penyebab gangguan kejiwaan bagi manusia modern. Pertama, kecemasan. Perasaan cemas yang diderita seseorang bersumber dari hilangnya makna hidup (the meaning of life), pada hal secara

${ }^{18}$ Syukur Kholil (ed.), Bimbingan Konseling dalam Perspektif Islam (Bandung: Citapustaka Media, 2009), h. 25-26.

${ }^{19}$ Departemen Agama, Al-Qur'an dan Terjemahannya, h. 445-446.

${ }^{20}$ Achmad Mubarok, Konseling Agama (Jakarta: Bina Rena Pariwara, 2002), h. 162. 
fitri manusia memiliki kebutuhan akan makna hidup. Makna hidup dimiliki oleh seseorang manakala ia memiliki kejujuran dan merasa hidupnya dibutuhkan oleh orang lain, dan merasa mampu dan telah mengerjakan sesuatu yang bermakna untuk orang lain. Makna hidup biasanya dihayati oleh para pejuang atau mujahid, karena pusat perhatian pejuang adalah pada bagaimana bisa menyumbangkan sesuatu untuk kepentingan dan kemaslahatan orang lain. Berbeda halnya dengan manusia modern, mereka tidak memiliki makna hidup, tujuan hidup dan prinsip hidup. Apa yang dilakukan tidak lebih dari sekedar mengikuti trend, mengikuti tuntutan sosial, sedangkan tuntutan sosial tersebut belum tentu berdiri di atas suatu prinsip yang mulia. Dengan kata lain, manusia modern cenderung mengikuti kehendak yang sesaat dan terkadang hanya sekedar ingin dikatakan orang lain bisa mengikuti zaman, sementara jauh di balik itu atau sesuatu yang tercecer dan hilang yaitu kepribadian yang sejati. Seseorang terkadang berupaya untuk bersandiwara di hadapan orang lain atau dalam lingkungan sosialnya, tetapi sebenarnya pada waktu yang bersamaan, ia sedang mengalami kecemasan dan kegelisahan.

Kedua, kesepian. Kesepian bersumber dari hubungan antar manusia (interpersonal) di kalangan masyarakat modern yang tidak lagi tulus, ikhlas dan hangat. Kegersangan hubungan antar manusia disebabkan karena kebanyakan manusia medern menggunakan topeng-topeng sosial untuk menutupi wajah kepribadiannya. Orang tidak lagi berbuat sesuai dengan nuraninya, tetapi lebih cenderung berbuat demi nafsu dan kepentingan sesaat, atau seseorang yang berdiri di balik topeng. Jika ia melakukan hubungan atau komunikasi dengan orang lain, ia selalu berada bukan pada dirinya yang sebenarnya, tetapi ia memiliki topeng yang dapat mengelabui orang lain. Orang seperti ini adalah orang-orang yang telah kehilangan jati dirinya, dan sebagai akibatnya ia mudah mengidap perasaan sepi, sunyi dan gelisah walaupun ia berada di tengah-tengah keramaian dan kerumunan manusia. Karena itu, kesepian dan kesunyian sebenarnya tidak diukur dengan kuantitas atau jumlah/fisik, tetapi sangat ditentukan oleh aspek psikis atau perasaan.

Ketiga, kebosanan. Manakala seseorang tidak memiliki tujuan dan prinsip hidup yang jelas, maka ia akan merasakan kehidupan yang hambar, kecemasan selalu mengganggu jiwanya dan kesepian yang berkepanjangan akan melanda manusia, dan jika hal itu telah terjadi, seseorang itu akan menderita gangguan kejiwaan berupa kebosanan. Kecemasan dan kesepian yang berkepanjangan, yang pada akhirnya membuat seseorang itu bosan, bosan kepada kepura-puraan dan bosan kepada kepalsuan. Kebosanan juga bisa terjadi karena manusia melakukan sesuatu yang tidak sesuai dengan nalurinya, atau juga bisa disebakan karena seseorang itu telah keliru dalam memaknai hidup ini. Kebosanan seperti ini akan menyebabkan seseorang mudah cemas, gelisah dan depresi.

Keempat, perilaku menyimpang. Manusia yang dihinggapi perasaan cemas, kesepian dan kebosanan, menyebabkan seseorang itu tidak tahu apa yang harus ia lakukan. Dalam keadaan jiwa yang kosong dan rapuh seperti ini, seseorang tidak mampu berpikir secara jernih dan kritis. Kekosongan jiwa itu dapat membuat seseorang melakukan apa saja, 
seperti meminum minuman yang memabukkan, merampok, memperkosa dan membunuh orang tanpa sebab yang jelas. Ia merasa apa yang dilakukannya itu seakan-akan memberikan hiburan baginya, tetapi sebenarnya jauh di balik semua itu, dia telah melakukan perbuatan yang menyimpang dan telah jauh dari kebenaran. Perilaku menyimpang yang dilakukan seseorang bukan hanya berdampak negatif kepada orang lain, karena orang yang di sekitarnya merasa tidak nyaman, tetapi juga bisa berdampak negatif terhadap dirinya sendiri.

Kelima, psikosomatik. Psikosomatik adalah gangguan fisik yang disebabkan oleh faktor-faktor kejiwaan dan sosial. Jika emosi seseorang menumpuk dan memuncak, maka hal seumpama itu dapat menyebabkan terjadinya kekacauan dalam dirinya. Jika faktorfaktor yang menyebabkan memuncaknya emosi tidak dapat dijauhkan, maka hal itu dapat memengaruhi fisiknya. Penderita penyakit psikosomatik biasanya selalu mengeluh, merasa tidak enak badan, jantungnya berdebar-debar, merasa lemah, lemas dan tidak bisa berkonsentrasi. Wujud psikosomatik bisa terlihat dalam bentuk syndrome, trauma, stress, ketergantungan kepada obat penenang/alkohol/narkotik atau perilaku menyimpang lainnya. Karena itu, setiap konselor sebaiknya dapat mengendalikan dan mengarahkan klien yang menderita penyakit psikosomatik ini melalui berbagai macam terapi/pengobatan, salah satu dan yang paling banyak membantu adalah pendekatan agama, yaitu memperbanyak membaca al-Qur'an.

Menurut Dadang Hawari, ${ }^{21}$ penyebab utama munculnya masalah dalam masyarakat modern adalah timbulnya disintegrasi dari masyarakat tradisional karena unsur-unsurnya mengalami perubahan dengan kecepatan yang berbeda. Kebenaran-kebenaran yang abadi sebagaimana terkandung dalam ajaran agama, disisihkan karena dianggap kuno sehingga orang hanya berpegang kepada kebutuhan materi dan tujuan sementara. Dalam masyarakat modern, rongrongan terhadap agama, moral, budi pekerti, warisan budaya lama dan tradisional telah menimbulkan ketidakpastian fundamental di bidang hukum, moral, nilai dan etika kehidupan. Perubahan-perubahan sosial yang cepat sebagai akibat modernisasi telah menyebabkan manusia kehilangan identitas diri.

Selain itu, menurut Tohirin, ${ }^{22}$ siswa di sekolah dapat dipastikan memiliki masalah, tetapi kompleksitas masalah yang dihadapi masing-masing individu berbeda. Menurutnya, ada lima jenis masalah yang dihadapi oleh siswa di sekolah, yaitu perkembangan individu; perbedaan individu dalam kecerdasan, kecakapan, hasil belajar, bakat, sikap, kebiasaan, pengetahuan, kepribadian, ciri-ciri jasmaniyah dan latar belakang lingkungan; kebutuhan individu dalam hal memperoleh kasih sayang, memperoleh harga diri, memperoleh penghargaan, ingin dikenal, memperoleh prestasi dan posisi, rasa aman, perlindungan dan lainlain; penyesuaian diri serta kelainan tingkah laku dan masalah belajar/pendidikan.

\footnotetext{
${ }^{21}$ Dadang Hawari, Al-Qur'an Ilmu Kedokteran Jiwa dan Kesehatan Jiwa (Yogyakarta: Dana Bakti Prima Yasa, 1997), h. 3.

${ }^{22}$ Tohirin, Bimbingan dan Konseling di Sekolah dan Madrasah (Jakarta: RajaGrafindo Persada, 2007), h. 111.
} 
Permasalahan yang muncul ke permukaan erat kaitannya dengan adanya gangguan

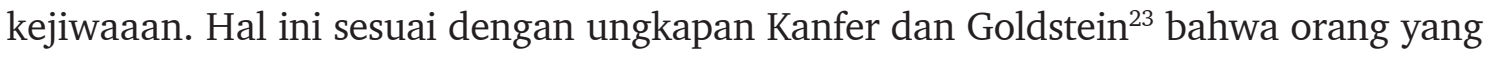
mengalami gangguan kejiwaan dapat terlihat pada empat ciri yaitu hadirnya perasaan cemas (anxiety) dan perasaan tegang (tension) di dalam diri, merasa tidak puas terhadap perilaku diri sendiri, perhatian yang berlebih-lebihan terhadap problem yang dihadapi dan ketidakmampuan berfungsi secara efektif di dalam menghadapi problem.

Menurut Djamaluddin Ancok dan Fuat Nashori Suroso, ${ }^{24}$ bahwa penyebab gangguan kejiwaan itu bermacam-macam, ada yang besumber dari hubungan dengan orang lain yang tidak memuaskan, seperti diperlakukan tidak adil, diperlakukan semena-mena, cinta tidak terbalas, kehilangan seseorang yang dicintai dan kehilangan pekerjaan. Selain itu, ada pula gangguan jiwa yang disebabkan oleh faktor organik, seperti kelainan sistem syaraf, dan gangguan pada otak.

Berdasarkan berbagai pandangan dan fenomena sebelumnya dipahami bahwa penyebab utama mudahnya seseorang terserang permasalahan dan dihinggapi penyakit mental adalah disebabkan seseorang tidak mampu menerima dirinya dengan baik, tidak bisa menyesuaikan diri dengan lingkungan dan jauhnya seseorang dari Allah SWT. Sebaliknya, seseorang akan terhindar dari penyakit mental apabila seseorang itu dapat menyesuaikan diri, dekat kepada Allah SWT., sayang serta santun kepada sesama manusia.

\section{Tahap-tahap Psikoterapi}

Menurut Prawitasari seperti dikutip Rahayu, ${ }^{25}$ psikoterapi atau terapi kejiwaan dikembangkan melalui tahap-tahap berikut. Pertama, wawancara awal. Pada tahap awal ini perlu dirumuskan tentang apa yang akan terjadi selama terapi berlangsung. Aturanaturan apa saja yang harus diketahui dan akan dilaksanakan oleh konseli/klien. Dalam tahap awal ini perlu dibina rapport yaitu hubungan baik yang menimbulkan keyakinan dan kepercayaan klien bahwa ia akan dapat ditolong. Dalam tahap awal ini juga klien harus bersedia mengutarakan pikiran dan perasaannya kepada konselor.

Kedua, proses terapi. Pada tahap ini, terapis (konselor) perlu mengkaji dan mendalami pengalaman klien, menggali pengalaman masa lalu selama hal itu relevan dengan permasalahan yang dihadapi oleh klien. Hal yang tidak kalah pentingnya adalah menghidupkan suasana keakraban dan komunikasi dua arah.

Ketiga, tindakan. Pada tahap ini, baik terapis maupun klien mengkaji ulang kembali apa yang telah dipelajari klien selama terapi berlangsung, dan apa yang akan diterapkan-

\section{h. 7 .}

${ }^{23}$ Kanfer F.H., \& AP Goldstein, Helping People Change (New York: Pergamon Press, 1982),

${ }^{24}$ Djamaluddin Ancok dan Fuat Nashori Suroso, Psikologi Islami (Yogyakarta: Pustaka Pelajar, 2004), h. 91-92.

${ }^{25}$ Rahayu, Psikoterapi Perspektif, h. 206-207. 
nya nantinya dalam kehidupannya. Hal yang sangat penting dilakukan adalah agar tujuan terapi yang telah disepakati bersama dapat tercapai.

Keempat, mengakhiri terapi. Terapi dapat berakhir kalau tujuan telah disepakati, namun bisa juga terapi berakhir apabila klien tidak melanjutkan terapi. Terapi juga bisa berakhir apabila terapis tidak dapat menolong kliennya, namun terapis sebaiknya merujuk kliennya kepada ahli lain sesuai dengan jenis masalah/problem yang dihadapi oleh klien tersebut. Terapis harus menghilangkan sedikit demi sedikit ketergantungan klien terhadap dirinya, karena klien akan menghadapi lingkungannya tanpa bantuan terapis (konselor).

\section{Model-model Psikoterapi dalam al-Qur'an dan Sunnah Rasul}

Menurut al-Zahrani, ${ }^{26}$ terdapat delapan model terapi mental dalam al-Qur'an dan Sunnah Rasul. Pertama, psikoterapi dengan keimanan. Terapi keimanan adalah keimanan murni melalui ibadah kepada Allah SWT. Keimanan seperti inilah yang mendatangkan ketenangan dan juga petunjuk ke jalan kebenaran dan kebaikan. Dalam kaitan ini, jika konseli/klien mempunyai masalah atau gangguan kejiwaan, maka konselor menganjurkan agar memperbaiki keimanan atau dekat dengan Allah. Dekat kepada Allah bermakna klien berupaya untuk memperbanyak ibadah dan selalu ingat kepada Allah, dengan terapi seperti ini diharapkan jiwa manusia semakin tentram dan damai. Sesuai dengan firman Allah,

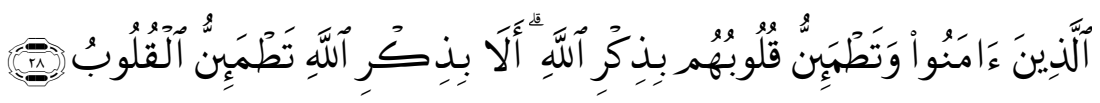

Orang-orang yang beriman dan hati mereka menjadi tenteram dengan mengingat Allah. Ingatlah, hanya dengan mengingati Allah-lah hati menjadi tenteram (Q.S. al-Ra'd/13: 28). ${ }^{27}$

Terealisasinya ketenangan diri dan keamanan dalam hati seseorang mukmin muncul dari keimanannya yang murni kepada Allah, hingga ia selalu memiliki harapan dalam mendapatkan pertolongan dan penjagaan dari-Nya. Setiap mukmin hendaknya selalu menghadapkan wajahnya kepada Allah SWT. di saat ia beribadah dan selalu meniatkan semua yang dilakukannya demi mengharapkan keridaan-Nya semata. Dengan demikian, ia akan selalu merasa bahwa Allah selalu bersamanya dan dalam pertolonganNya setiap saat.

Kedua, psikoterapi melalui ibadah. Menunaikan ibadah merupakan salah satu cara untuk menghapuskan dosa dan memperkuat ikatan seorang mukmin kepada Allah SWT. dengan selalu mematuhi perintah Allah dan menjauhi dari segala larangan-Nya. Dengan memperbanyak dan memperbaiki kualitas ibadah kepada Allah, maka akan muncul sebuah

${ }^{26}$ Musfir bin Said Az-Zahrani, Konseling Terapi, terj. Sari Narulita dan Miftahul Jannah (Jakarta: Gema Insani,2005), h. 470-504.

${ }^{27}$ Departemen Agama, Al-Qur'an dan Terjemahannya, h. 341. 
harapan bahwa Allah dapat mengampuni segala kesalahannya. Terapi mental melalui ibadah ini lebih terlihat lagi dari ibadah salat. Melalui ibadah salat terjadi suatu ikatan atau hubungan yang kuat antara hamba dengan Tuhannya. Dalam salat, seorang hamba dengan penuh harap dan kekhusukan memohan kepada Allah agar ia selalu mendapatkan kebahagiaan dan keselamatan baik di dunia maupun di akhirat. Perasaan seperti ini pada akhirnya dapat melahirkan kejernihan spiritualitas, ketenangan hati dan keamanan diri dikala ia mengerahkan semua emosi dan anggota tubuhnya kepada Allah. Pada saat salat juga setiap hamba dapat sepenuhnya merasakan ketenangan jiwa dan akalnya pun selalu terbimbing dengan sempurna.

Ketiga, psikoterapi dengan puasa. Puasa merupakan salah satu latihan dan didikan jiwa dan banyak mengandung terapi penyakit kejiwaan dan penyakit fisik. Karena itu, bagi orang yang sakit fisik (selama penyakit itu tidak berbahaya) lebih baik berpuasa, karena melalui puasa bisa menjadikan fisik semakin sehat (shûmû tashihhû). Di saat berpuasa inilah seorang Muslim selalu berusaha untuk berperilaku baik dan mendengarkan kata hatinya walaupun tidak ada satu orangpun yang mengawasi perilakunya. Dengan berpuasa juga seseorang akan berlatih untuk bersabar atas lapar dan haus serta dalam menahan syahwatnya.

Keempat, psikoterapi melalui ibadah haji. Ibadah haji dapat melahirkan sifat-sifat yang mulia, seperti kebersamaan, kesatuan pandangan di samping mendekatkan diri kepada Allah SWT. dengan memperbanyak mengalunkan kalimat-kalimat talbiyah. Haji merupakan pusat pelatihan bagi umat Islam, karena dalam ibadah haji seseorang akan selalu mengingat Allah, selalu berdoa kepada-Nya, melakukan salat dengan penuh kekhusukan, dan memotong hewan kurban bagi yang tidak sedang melaksanakan ibadah haji. Melalui ibadah haji ini juga seseorang melatih diri lebih rendah hati, disiplin dan mengubur jauhjauh sifat sombong dan berbangga diri. Haji merupakan salah satu psikoterapi atas perasaan bersalah dan berdosa, karena melalui ibadah haji dosa dan kesalahan dapat diampuni.

Kelima, psikoterapi melalui sabar. Sabar adalah salah satu penyebab datangnya keberuntungan, kemenangan dan kebahagiaan, karena orang yang sabar atas segala ujian dan cobaan dari Allah SWT. akan diberikan pahala atau balasan yang lebih baik. Sabar dan sifat saling mengingatkan untuk bersabar adalah dua hal yang masuk dalam cakupan ibadah dan cakupan hubungan interaksi manusia dengan sesamanya. Sabar memiliki manfaat yang besar dalam mendidik jiwa dan menguatkan kepribadian Muslim sehingga menambah kekuatannya untuk dapat memikul beban kehidupan, dan memperbarui kembali semangat untuk menghadapi segala permasalahan hidup.

Keenam, psikoterapi melalui istighfar dan taubat. Ucapan istighfar dan bertaubat kepada Allah SWT. merupakan sesuatu yang sangat dianjurkan dalam ajaran Islam, karena pada dasarnya setiap manusia pernah bersalah atau berdosa baik kecil maupun besar. Hal ini sesuai dengan penjelasan Rasulullah SAW. dalam sabdanya "Setiap anak Adam pernah bersalah, dan sebaik-baik orangyang bersalah adalah orangyang mau bertaubat" (H.R. Ahmad). Orang yang sering istighfar dan bertaubat kepada Allah adalah orang yang 
menyadari sepenuhnya bahwa dirinya pernah berbuat salah dan dosa, kemudian ia berjanji kepada Allah dan kepada dirinya sendiri untuk tidak mengulangi perbuatan yang tidak baik tersebut. Orang yang menyadari bahwa dia mempunyai kesalahan, ia akan selalu istighfar dan bertaubat kepada Allah. Penyesalan terhadap dosa yang pernah dilakukan seorang terhadap Allah merupakan salah satu bentuk psikoterapi atau terapi kejiwaan.

Ketujuh, psikoterapi melalui zikir. Semua ibadah termasuk zikir pada hakikatnya adalah usaha untuk mengingat Allah. Zikir atau mengingat Allah sangat dianjurkan dalam ajaran Islam, bahkan zikir (salat) adalah sebaik-baik ibadah. Orang-orang yang selalu mengingat Allah baik dengan takbir, tasbih, tahmid dan tahlil, maka jiwanya semakin damai, tenang dan tenteram. Zikir dengan penuh penghayatan dan keikhlasan dapat menghilangkan penyakit psikis yang diderita oleh manusia. Hal ini sesuai dengan firman Allah,

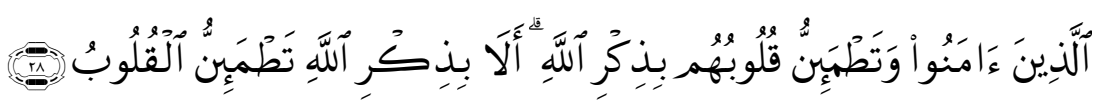

Orang-orang yang beriman dan hati mereka manjadi tenteram dengan mengingat Allah. Ingatlah, Hanya dengan mengingati Allah-lah hati menjadi tenteram (Q.S. al-Ra'd/13: 28). ${ }^{28}$

Kedelapan, terapi dengan doa. Doa merupakan salah satu senjata yang sangat ampuh bagi umat Islam, dan merupakan sarana ibadah dalam mengingat Allah SWT. Orang yang berdoa kepada Allah adalah orang yang mempunyai harapan dan keyakinan bahwa Allah akan mengabulkan harapan dan doanya. Bagi orang yang berdoa sangat dianjurkan untuk yakin dan penuh optimisme bahwa doanya akan diterima Allah. Hal ini sesuai dengan firman-Nya,

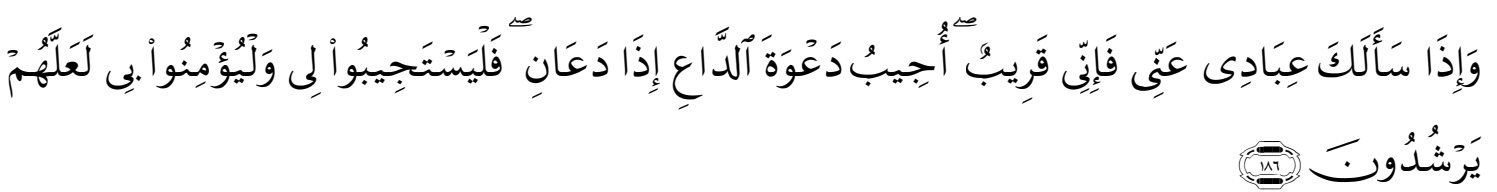

Dan apabila hamba-hamba-Ku bertanya kepadamu tentang Aku, maka (jawablah), bahwasanya Aku adalah dekat. Aku mengabulkan permohonan orang yang berdoa apabila ia memohon kepada-Ku, maka hendaklah mereka itu memenuhi (segala perintah-Ku) dan hendaklah mereka beriman kepada-Ku, agar mereka selalu berada dalam kebenaran (Q.S. al-Baqarah/2: 186). ${ }^{29}$

Berdasarkan ayat ini, maka ada dua syarat utama yang harus dipenuhi oleh seseorang yang berdoa agar doanya diterima oleh Allah SWT., yaitu orang yang berdoa harus benarbenar melaksanakan perintah Allah dan orang yang berdoa harus benar-benar beriman kepada Allah dalam arti yang sesunguhnya. Terapi doa bukan hanya berguna untuk

${ }^{28}$ Ibid, h. 341.

${ }^{29}$ Ibid, h. 35. 
menyembuhkan penyakit kejiwaan, tetapi juga bisa digunakan untuk menyembuhkan penyakit fisik. Hal ini pernah dicontohkan oleh Rasulullah SAW. ketika beliau menjenguk salah seorang keluarganya yang sakit. Ia berdoa "Allâhumma rabb al-nâsi azhib al-ba'sa asyfi anta al-syâfi syifâ'a illa syifâ' uka, syifâ' la yugâdiru saqama," (Ya Allah Tuhan dari semua manusia, hilangkan segala penyakit, sembuhkanlah, hanya Engkau yang dapat menyembuhkan, tiada kesembuhan kecuali daripada-Mu, sembuh yang tidak dihinggapi penyakit lagi”' (H.R. Bukhârî dan Muslim dari 'A'isyah). ${ }^{30}$

Dengan demikian, setiap konselor Islami dapat menyarankan atau menganjurkan kedelapan jenis psikoterapi Islami ini kepada klien walaupun secara bertahap sehingga akhirnya klien dapat keluar dari permasalahan yang dihadapi. Pada akhirnya, klien dapat merasakan kedamaian, ketentraman dan kebahagiaan yang hakiki.

Pada sisi lain, menurut Arifin, ${ }^{31}$ ada empat macam psikoterapi/terapi kejiwaan yang bisa dilakukan konselor terhadap orang yang menderita masalah maupun gangguan kejiwaan. Pertama, terapi psikofarmaka, yaitu terapi fisik biologis, dengan obat-obatan anti depresi yang berpengaruh terhadap perkembangan jiwa pasien yang terkena depresi. Kedua, terapi psikologis atau sering juga disebut sebagai psikoterapi biasa, yaitu terapi terhadap gangguan-gangguan kejiwaan dengan asas-asas dan pendekatan psikologi Barat. Ketiga, terapi psikososial, yaitu terapi dengan asas-asas psikologi untuk pasien-pasien yang mengalami gangguan maladaptif atau malasuai terutama secara sosial. Keempat, terapi psiko-spiritual atau disebut juga terapi psiko-relegius. Terapi ini lebih menekankan pada pasien agar mendekatkan diri kepada Allah SWT. melalui ibadah, berzikir dan berdoa. Pandangan ini menggabungkan antara pendekatan psikologi dan agama dalam memberikan penyembuhan terhadap klien yang mengalami problem atau mengalami gangguan kejiwaan.

Sementara itu, menurut Wolberg, seperti dikutip oleh Amin, ${ }^{32}$ tipe terapi atau penyembuhan dapat dikelompokkan kepada tiga bagian. Pertama, penyembuhan suportif (supportive therapy). Tujuan supportive therapy adalah memperkuat benteng-benteng pertahanan (harga diri dan kepribadian), memperluas mekanisme pengarahan dan pengendalian emosi, dan pengembalian pada penyesuaian diri yang seimbang. Metode dan teknik pendekatannya, bimbingan (guidance), mengubah lingkungan (environmental manipulation), pengaturan dan penyaluran arah minat, meyakinkan (reassurance), tekanan dan pemaksaan (preassure and coercion), penebalan perasaan (desensitization), penyaluran emosional atau katarsis, sugesti (suggestion) dan Penyembuhan inspirasi berkelompok (inspiration group therapy).

Kedua, penyembuhan reedukatif (reeducative therapy). Tujuan reedukatif terapi adalah penyesuaian kembali, perubahan atau modifikasi sasaran atau tujuan, dan meng-

\footnotetext{
${ }^{30}$ Salim Bahreisy, Terjemahan Riyadhus Shalihin (Bandung: Al-Ma'arif, 1985), h. 63.

${ }^{31}$ Arifin, Bimbingan Penyuluhan h. 26.

${ }^{32}$ Amin, Bimbingan dan Konseling, h. 95-97.
} 
hidupkan potensi kreatif. Untuk mencapai tujuan tersebut dapat diusahakan adanya pemahaman (insight). Metode atau teknik pendekatannya antara lain adalah penyembuhan sikap (attitude therapy), penyembuhan kelakuan dan pembiasaan, wawancara, penyembuhan terpusat pada klien (client centered therapy), penyembuhan terarah, penyuluhan terapiutik, penyembuhan rasional, pendekatan filosofis, penyembuhan semantik, penyembuhan reedukatif, psikodrama, penyembuhan keluarga, penyembuhan perkawinan dan penyembuhan psikobiologis.

Ketiga, penyembuhan rekonstruktif (recontructive therapy). Tujuan rekonstruktif terapi adalah menimbulkan insight atau penyembuhan terhadap konflik-konflik yang tidak disadari agar terjadi perubahan struktur karakter, dan perluasan pertumbuhan kepribadian dengan mengembangkan potensi penyesuaian yang baru. Metode dan teknis pendekatannya antara lain psikoanalisis (terdiri atas Freudian, Neo-Freudian Psychoanalysis, Ego analysis dan Kleinian Analysis), pendekatan transaksional, analisis eksistensial, penyembuhan analitik berkelompok, penyembuhan bermain dan psikoterapi dengan orientasi psikoanalisis.

Dari beberapa jenis terapi yang dijelaskan di atas, konselor dapat memilih psikoterapi yang sesuai dengan masalah dan gejala gangguan kejiwaan yang dihadapi oleh klien. Psikoterapi yang paling tepat adalah melalui spiritual atau terapi religius, hal ini dapat dibuktikan ketika manusia dekat kepada Allah SWT., maka seseorang itu memiliki ketenangan batin. Ketika seseorang telah sampai ke tahap itu, maka seseorang itu akan terhindar dari penyakit stress, depresi, was-was dan cemas, dan pada waktu yang bersamaan seseorang itu dapat menghadapi dan mengatasi berbagai persoalan dengan bijaksana.

\section{Tujuan Psikoterapi dalam Bimbingan Konseling Islami}

Menurut Gerald Corey, ${ }^{33}$ tujuan psikoterapi adalah untuk penyusunan kembali kepribadian, penemuan makna dalam hidup, penyembuhan gangguan emosional, penyesuaian terhadap masyarakat, pencapaian kebahagiaan dan kepuasan, pencapaian aktualisasi diri, peredaan kecemasan serta penghapusan tingkah laku mal-adaptif dan belajar tingkah laku adaptif. Sedangkan tujuan psikoterapi dalam perspektif Bimbingan Konseling Islami adalah agar seseorang yang mempunyai masalah gangguan kejiwaan baik mental, spiritual, moral dan fisik, dapat teratasi atau berkurang dari masalah yang dideritanya melalui arahan, bimbingan dan tuntunan dari konselor/terapis Islami melalui pendekatan alQur'an dan Sunnah.

Menurut Thohari Musnamar, ${ }^{34}$ tujuan Bimbingan dan Konseling Islami adalah membantu individu mewujudkan dirinya sebagai manusia seutuhnya agar mencapai

\footnotetext{
${ }^{33}$ Corey, Teori dan Praktek, h. 318.

${ }^{34}$ Thohari Musnamar, Dasar-dasar Konseptual Bimbingan dan Konseling Islami (Yogyakarta: UII Press, 1992), h. 33.
} 
kebahagiaan hidup di dunia dan di akhirat. Kebahagiaan hidup di dunia dapat ditandai ketika manusia/klien terlepas dan terbebas dari problema yang dapat memengaruhi kestabilan emosional seseorang, atau terjauh dari perasaan was-was, cemas, gelisah dan depresi. Sementara kebahagiaan akhirat dapat dirumuskan apabila terlepas dan terbebas dari siksa neraka, dan sebaliknya dimasukkan ke dalam surga sebagai tempat dan balasan bagi orang-orang yang beriman dan beramal kebaikan. Kebahagiaan dunia akhirat merupakan dambaan dan harapan setiap umat Islam. Hal ini sesuai dengan doa yang selalu diucapkan oleh setiap umat Islam dalam doanya seperti yang termaktub dalam al-Qur'an:

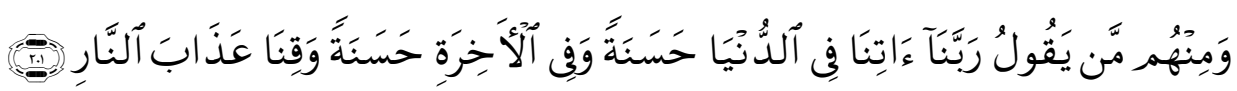

Dan di antara mereka ada orangyang bendoa: 'Ya Tuhan kami, berilah kami kebaikan di dunia dan kebaikan di akhirat dan peliharalah kami dari siksa neraka.' (Q.S. al-Baqarah/2: 201). ${ }^{35}$

Konsep kebahagiaan itu sebenarnya masih abstrak dan ukurannya pun tidak sama bagi setiap orang, hal itu sangat tergantung dari cara pandang seseorang. Namun dalam analisis psikologi dan konseling, seseorang akan bahagia apabila seseorang itu terlepas dari neurose dan psikosis atau terlepas dari gejala gangguan kejiwaan dan gelaja penyakit jiwa. Sementara upaya untuk menghindari atau agar terjauh dari penyakit tersebut, manakala seseorang itu dekat kepada Allah SWT.

Tujuan akhir dari Bimbingan Konseling Islami atau psikoterapi Islami adalah agar klien terhindar dari berbagai masalah, apakah masalah tersebut berkaitan dengan gejala penyakit mental (neurose dan psychose), sosial dan spiritual, atau dengan kata lain agar masing-masing individu memiliki mental yang sehat. ${ }^{36}$

Jiwa/hati yang sehat (qalb al-salîm) adalah hati yang senantiasa bertawakkal, bersyukur, sabar, tabah, rendah hati, rajin beribadah, warak, ikhlas, amanah dan berjihad di jalan Allah SWT. Wahananya adalah zikir, taubat, cinta ilmu dan rindu terhadap hidayah Allah. Dengan demikian, psikoterapi dalam perspektif bimbingan konseling Islami adalah suatu usaha yang dilakukan konselor terhadap kliennya, agar kliennya dapat keluar dari berbagai masalah, baik masalah kejiwaan, spiritual, akhlak dan fisik, dan menyarankan kepada klien agar mereka dekat kepada Allah SWT. melalui berbagai macam ibadah, seperti melaksanakan salat, menunaikan zakat, puasa, haji, sabar, istighfar, zikir dan doa, berakhlak yang mulia serta menjauhi dari segala larangan-Nya.

${ }^{35}$ Departemen Agama, Al-Qur'an dan Terjemahannya,h. 39.

${ }^{36}$ Lahmuddin Lubis, Bimbingan Konseling Islami (Jakarta: Hijri Pustaka Utama, 2007), h. 26; Lahmuddin Lubis, Konsep-konsep Dasar Bimbingan Konseling (Bandung: Citapustaka Media, 2006). 


\section{Penutup}

Psikoterapi (psychotherapy) dalam perspektif Bimbingan Konseling Islami adalah suatu proses penyembuhan atau perawatan (treatment) yang dilakukan oleh konselor (terapis) yang profesional kepada konseli/klien melalui pendekatan psikologi, al-Qur'an dan hadis, dengan tujuan agar klien dapat keluar dari masalah yang dihadapinya, baik masalah kejiwaan, spiritual (keagamaan), akhlak maupun masalah fisik. Psikoterapi dapat dilakukan melalui beberapa cara yaitu meningkatkan keimanan dan ibadah klien, mendalami dan mengamalkan al-Qur'an, terapi kejiwaan melalui salat, melalui zakat, melalui puasa, melalui haji, melalui kesabaran, melalui istighfar dan taubat serta terapi melalui zikir dan doa.

Psikoterapi atau terapi kejiwaan yang paling ampuh dalam perspektif Bimbingan Konseling Islami adalah mendekatkan diri kepada Allah SWT. dengan melakukan berbagai macam ibadah dan menjauhi dari segala larangan-Nya. Seseorang yang dekat kepada Allah, hatinya semakin tenang dan tenteram, jiwanya semakin lapang, pikirannya semakin jernih dan fisiknya semakin sehat. Ketika kepribadian/kejiwaan klien telah sampai ke tahap ini, maka berbagai penyakit fisik dan psikis akan terhindar darinya.

\section{Pustaka Acuan}

Amin, Samsul Munir. Bimbingan dan Konseling Islam. Jakarta: AMZAH, 2010.

Ancok, Djamaluddin dan Fuat Nashori Suroso. Psikologi Islami. Yogyakarta: Pustaka Pelajar, 2004.

Arifin, Isep Zainal. Bimbingan Penyuluhan Islam Pengembangan Dakwah Melalui Psikoterapi Islam. Jakarta: RajaGrafindo Persada, 2009.

Az-Zahrani, Musfir bin Said. Konseling Terapi, terj. Sari Narulita dan Miftahul Jannah. Jakarta: Gema Insani, 2005.

Bahreisy, Salim. Riyadhus Shalihin, Jilid II. Bandung: Al-Ma'arif, 1985.

Corey, Gerald. Teori dan Praktek Konseling \& Psikoterapi, terj. E. Koeswara. Bandung: Refika Aditama, 2005.

Departemen Agama RI. Al-Qur'an dan Terjemahannya. Jakarta: Lintas Media, 2006.

Erhamwilda. Konseling Islami. Yogyakarta: Graha Ilmu, 2009.

Gladding, Samuel T. Counseling A Comprehensive Profession. Englewood Cliffs: Prentice Hall. Inc., 1996.

Hawari, Dadang. Al-Qur'an. Ilmu Kedokteran Jiwa dan Kesehatan Jiwa. Yogyakarta: Dana Bakti Prima Yasa, 1997.

Kanfer F.H., \& A.P. Goldstein. Helping People Change. New York: Pergamon Press, 1982.

Kholil, Syukur, (ed.). Bimbingan Konseling dalam Perspektif Islam. Bandung: Citapustaka Media, 2009. 
MIQOT Vol. XXXVI No. 2 Juli-Desember 2012

Lubis, Lahmuddin. Landasan Formal Bimbingan Konseling di Indonesia. Bandung: Citapustaka Media, 2011.

Lubis, Lahmuddin. Bimbingan Konseling Islami. Jakarta: Hijri Pustaka Utama, 2007.

Lubis, Lahmuddin. Konsep-konsep Dasar Bimbingan Konseling. Bandung: Citapustaka Media, 2006.

Mappiare, Andi. Kamus Istilah Konseling \& Terapi. Jakarta: RajaGrafindo Persada, 2006.

Mubarok, Achmad. Konseling Agama. Jakarta: Bina Rena Pariwara, 2002.

Musnamar, Thohari. Dasar-dasar Konseptual Bimbingan dan Konseling Islami. Yogyakarta: UII Press, 1992.

Qayyim, Ibnu. Terapi Penyakit dengan al-Qur'an dan Sunnah, terj. Achmad Sunarto. Jakarta: Pustaka Amani, 1999.

Rahayu, Iin Tri. Psikoterapi Perspektif Islam \& Psikologi Kontemporer. Malang: UIN MalangPress, 2009.

Tohirin. Bimbingan dan Konseling di Sekolah dan Madrasah. Jakarta: RajaGrafindo Persada, 2007. 